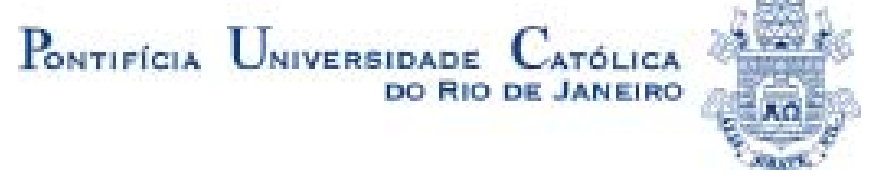

Silvio Montes Pereira Dias

\title{
Levantamento e análise nas operações logísticas internacionais através dos Portos do Rio de Janeiro
}

\begin{abstract}
Dissertação de Mestrado (Opção profissional)
Dissertação apresentada como requisito parcial para obtenção do título de Mestre pelo Programa de PósGraduação em Engenharia Industrial da PUC-Rio.
\end{abstract}

Orientador: Silvio Hamacher 
Silvio Montes Pereira Dias

\title{
Levantamento e análise nas operações logísticas internacionais através dos Portos do Rio de Janeiro
}

Dissertação apresentada como requisito parcial para obtenção do título de Mestre (opção profissional) pelo Programa de PósGraduação em Engenharia Industrial da PUC-Rio. Aprovada pela Comissão Examinadora abaixo assinada.

\author{
Prof. Silvio Hamacher \\ Orientador \\ Departamento de Engenharia Industrial - PUC-Rio \\ Prof. José Roberto de Souza Blaschek \\ Departamento de Informática - PUC-Rio \\ Prof. Leonardo Junqueira Lustosa \\ Departamento de Engenharia Industrial - PUC-Rio
}

Prof. José Eugênio Leal

Coordenador Setorial do Centro Técnico Científico - PUC-Rio

Rio de Janeiro, 12 de Abril 2004 
Todos os direitos reservados. É proibida a reprodução total ou parcial do trabalho sem autorização da universidade, do autor e do orientador.

\section{Silvio Montes Pereira Dias}

Graduou-se em Ciências Contábeis e especializou-se em Análise de Projetos e Gerência de Sistemas. Desenvolveu-se profissionalmente na Avalon Unit Assessoria Técnica Ltda na área de Logística Internacional. Atualmente é Diretor de Logística Internacional da Avalon Unit, além de ministrar aulas pela FGV/EBAP e FUNCEFET-RIO nas matérias de logística de transporte e comércio internacional.

Ficha Catalográfica

Dias, Silvio Montes Pereira

Levantamento e análise das operações logísticas internacionais através dos portos do Rio de Janeiro / Silvio Montes Pereira Dias ; orientador: Silvio Hamacher. - Rio de Janeiro : PUC, Departamento de Engenharia Industrial, 2004.

97 f. : il. ; $30 \mathrm{~cm}$

Dissertação (mestrado) - Pontifícia Universidade Católica do Rio de Janeiro, Departamento de Engenharia Industrial.

Inclui referências bibliográficas.

1. Engenharia industrial - Teses. 2. Logística. 3. Comércio exterior. 4. Logística internacional. I. Hamacher, Silvio. II. Pontifícia Universidade Católica do Rio de Janeiro. Departamento de Engenharia Industrial. III. Título. 


\section{Agradecimentos}

Ao meu orientador Professor Silvio Hamacher pelo incentivo e parceria para a realização deste trabalho.

A minha esposa Isabel, minhas filhas Michelle e Marcelle, ao meu pai Ataides, a minha mãe Hilda e a todos os familiares e amigos que sempre me apoiaram e me estimularam nas horas mais difíceis.

Aos meus colegas e professores da PUC-Rio.

Aos professores que participaram da comissão examinadora. 


\title{
Resumo
}

\begin{abstract}
Dias, Silvio Montes Pereira. Levantamento e Análise das Operações Logísticas Internacionais através dos Portos do Rio de Janeiro. Rio de Janeiro, 2004. 96p. Dissertação de Mestrado (Opção profissional) Departamento de Engenharia Industrial, Pontifícia Universidade Católica do Rio de Janeiro.
\end{abstract}

Este trabalho tem como objetivo apresentar os sistemas logísticos que, através do sistema portuário do país, dão suporte ao comércio exterior brasileiro. Esses sistemas visam essencialmente conferir ganhos competitivos em relação aos produtos exportados e importados, em termos de redução dos preços dos serviços logísticos e do lead time das operações.

Para atingir seu objetivo, inicialmente será apresentado o modelo logístico do comércio exterior brasileiro, que servirá para melhor visualizar os três importantes processos logísticos relacionados ao Comex, "Negociação", "Controle e Fiscalização" e "Transportes e Movimentação". Estes processos apresentarão como benefícios um menor lead time, menores custos e menores taxas de avarias.

Também será feito o levantamento e análise dos fluxos logísticos nos terminais portuários do Rio de Janeiro, que permitirá a apresentação da atual situação dos terminais portuários estabelecidos no estado do Rio de Janeiro, demonstrando os atuais índices operacionais. Além disso, deseja-se avaliar o grau de comprometimento dos terminais portuários em relação às operações e conseqüentes necessidades logísticas para o estado do Rio de Janeiro e aos estados usuários de sua infra-estrutura portuária.

Finalmente é apresentado o levantamento e análise dos fluxos logísticos de processos de importação desembaraçados no Rio de Janeiro, que, através da análise apresentada, servirá para a avaliação operacional dos processos e procedimentos adotados pelos operadores logísticos envolvidos nos referidos processos, buscando com isso determinar soluções para os principais problemas detectados.

\section{Palavras-chave}

Logística; Comércio Exterior; Portos; Aeroportos 


\section{Abstract}

Dias, Silvio Montes Pereira. Research and Analyzis of the Operations International Logistics through Ports of Rio de Janeiro. Rio de Janeiro, 2004. 96p. Dissertation of Master's degree (professional Option) Department of Engineering Industrial, Papal Catholic University of Rio de Janeiro.

This work has as objective presents the systems logistics that, through the port system of the country, will support the Brazilian External Trade. Those systems seek essentially to check competitive profits in relation to the exported and imported products, in terms of pricing reduction of the logistic services and the lead time of the operations.

To reach it's objective, the model logistic of the Brazilian external trade will be, initially presented, wich will support for the best visualization of the three important logistics 's processes related to trade international, "Negotiation", "Control and Fiscalization" and "Transports and Movement". These processes will present as benefits a smaller lead time, costs and taxes of mishaps.

It will also be done the research and analyzis of the logistics flows in the Rio de Janeiro port terminals, it will allow the presentation of the current situation of the port terminals established in the state of Rio de Janeiro, demonstrating the current operational indexes. Besides that, it's the intention to evaluate the degree of compromising of the port terminals regarding the operations and the consequent logistic needs for the state of Rio de Janeiro and to the users states of port infrastructure.

Finally the research and analyzis of the flows logístics of free import processes in Rio de Janeiro is presented, wich, through the presented analysis, will be used for operational evaluation of the processes and procedures adopted by the logistics's operators involved into referred processes, looking for determine solutions for the main detected problems.

\section{Keywords}

Logistics, International Trade, Ports, Airports 


\section{SUMÁRIO}

1. INTRODUÇÃO .............................................................. 1

2. COMÉRCIO EXTERIOR - IMPORTÂNCIA LOGÍSTICA ..... 4

IMPORTÂNCIA DO COMÉRCIO EXTERIOR ..............................................................

A IMPORTÂNCIA DA LOGÍSTICA PORTUÁRIA NO COMÉRCIO EXTERIOR ....................12

IMPORTÂNCIA E MODERNIZAÇÃo PORTUÁRIA BRASILEIRA ..................................14

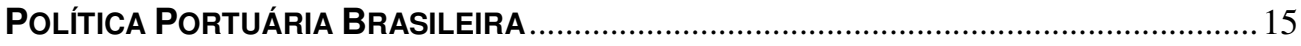

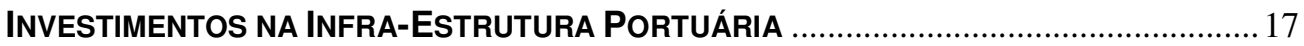

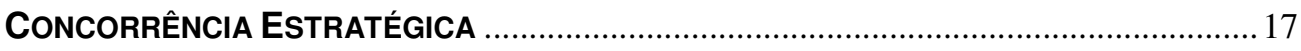

DESEMPENHO dOS SERVIÇOS PORTUÁRIOS BRASILEIROS ....................................18

PRINCIPAIS PORTOS DO ESTADO DO RIO DE JANEIRO ........................................19

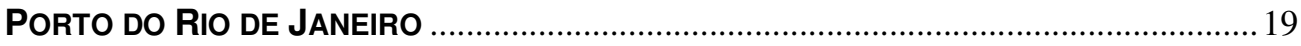

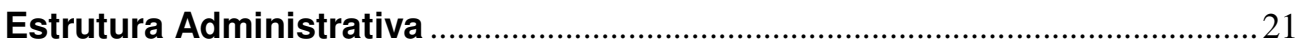

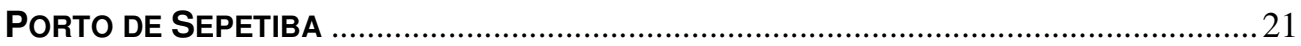

\section{MODELO LOGÍSTICO DO COMEX NO BRASIL................ 23}

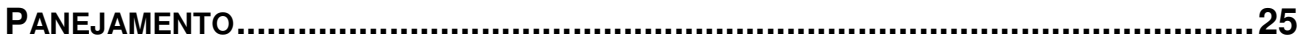

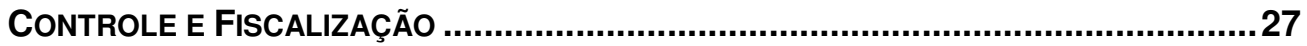

SISTEMAS INFORMATIZADOS DE CONTROLE E FISCALIZAÇÃO ..................................2 28

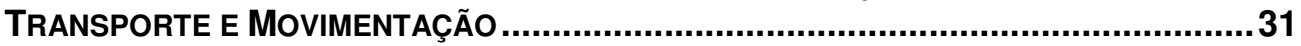

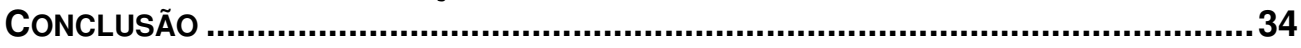

4. LEVANTAMENTO E ANÁLISE DOS FLUXOS LOGÍSTICOS NOS TERMINAIS PORTUÁRIOS DO RIO DE JANEIRO ...... 36

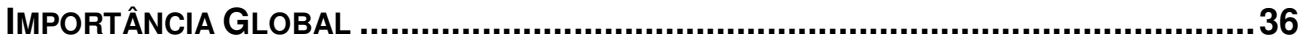

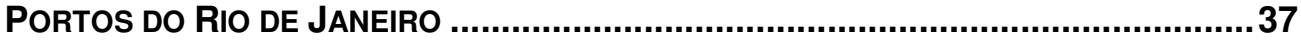

\section{LEVANTAMENTO E ANÁLISE DOS FLUXOS LOGÍSTICOS DE PROCESSOS DE IMPORTAÇÃO DESEMBARAÇADOS}

NO RIO DE JANEIRO......................................................... 44

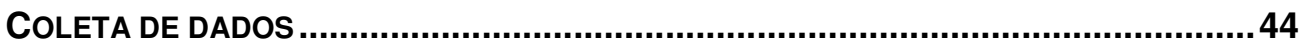

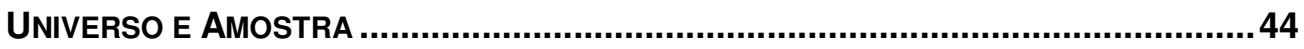

EXPLICAÇÃO DO FORMULÁRIO (TRATAMENTO DOS DADOS)...................................45

LIMITAÇÕES DO MÉTODO ............................................................................... 47

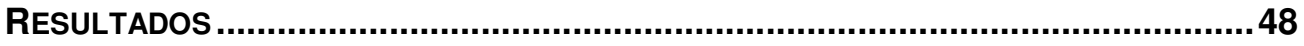

PrIMEIRA CONFIGURAÇÃo - ANÁLISE GLOBAL DOS DADOS ..................................... 48

SEGUNDA CONFIGURAÇÃo - ANÁLISE dOS CANAIS DE PARAMETRIZAÇÃo FISCAL

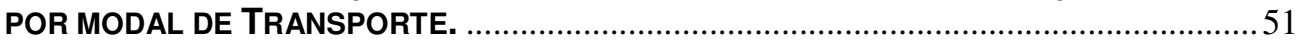

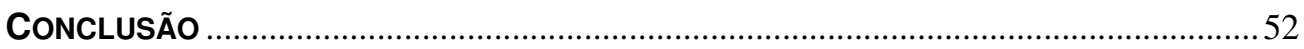

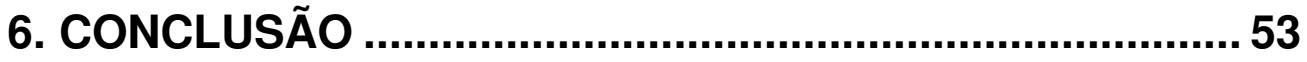


REFERÊNCIAS BIBLIOGRÁFICAS. ....................................57

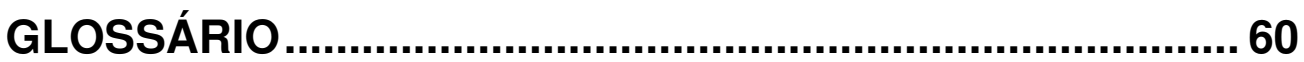

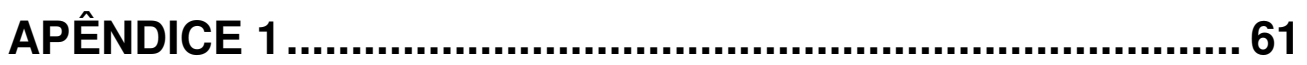

APÊNDICE 2

APÊNDICE 3

APÊNDICE 4 